\title{
Ectopic cutaneous Schistosomiasis
}

\author{
Esquistossomose cutânea ectópica
}

Thiago Jeunon de Sousa Vargas ${ }^{1}$

Maria de Lourdes Palermo F. N. Moraes ${ }^{3}$

Maria Auxiliadora Jeunon Sousa ${ }^{5}$

\author{
Raquel Lopes ${ }^{2}$ \\ Karen Grace Pena de Azevedo ${ }^{4}$
}

\begin{abstract}
The authors report a case of ectopic cutaneous schistosomiasis in a 35 year-old female who presented clustered reddish macules and papules on the left buttock. The diagnosis was not suspected during clinical evaluation and required visualization of Schistosoma mansoni eggs on sections of tissue.
\end{abstract}

Keywords: Schistosoma mansoni; Schistosomiasis mansoni; Skin

Resumo: Os autores relatam um caso de esquistossomose cutânea ectópica em uma paciente de 35 anos que apresentou máculas e pápulas eritematosas agrupadas na nádega esquerda. O diagnostico não foi suspeitado durante a avaliação clínica, tendo sido obtido através da visualização dos ovos no exame histopatológico.

Palavras-chave: Esquistossomose mansoni; Pele; Schistosoma mansoni

\section{CASE REPORT}

This was a thirty-five year-old, white, female patient born in Paraíba and resident in Jacarepaguá/RJ for the last 34 years. She presented with a cluster of reddish-coppery asymptomatic macules and papules on the left buttock, arising 30 days after a waterfall bathing at the countryside of the state (Figures 1 and 2). The diagnostic hypotheses were larva migrans, residual herpes simplex and sarcoidosis. Histopathological examination showed epithelioid granulomas surrounding eggs with an insinuation of a lateral spine, containing miracidia (Figure 3 and 4). Complete examination of gastrointestinal system and parasitological stool analysis did not show any alterations.

Received on 04.09.2012.

Approved by the Advisory Board and accepted for publication on 22.10.2012.

* Work performed at the Laboratory of Dermatology Investigation (ID)- Rio de Janeiro (RJ), Brazil.

Conflict of interest: None

Financial funding: None

Research fellow in Dermatology at the Ackerman Academy of Dermatopathology. - Preceptor at the Dermatology Service at Hospital Federal de Bonsucesso (HFB). Associate at the Laboratory of Dermatology Investigation (ID)- Rio de Janeiro (RJ), Brazil.

MD, dermatologist at private practice. Residency in Dermatology performed at Federal de Bonsucesso (HFB) - Bonsucesso (RJ), Brazil.

MD, PhD (in course) in Dermatology at University of São Paulo (USP) - São Paulo (SP), Brazil.

Chair Professor in Dermatology at University Iguaçu (UNIG) - Rio de Janeiro (RJ), Brazil.

Research fellowship in Dermatology at the New York University. Retired Assistant Professor at Rio de Janeiro State University (UERJ). Director at the Laboratory of Dermatology Investigation (ID)- Rio de Janeiro (RJ), Brazil. 


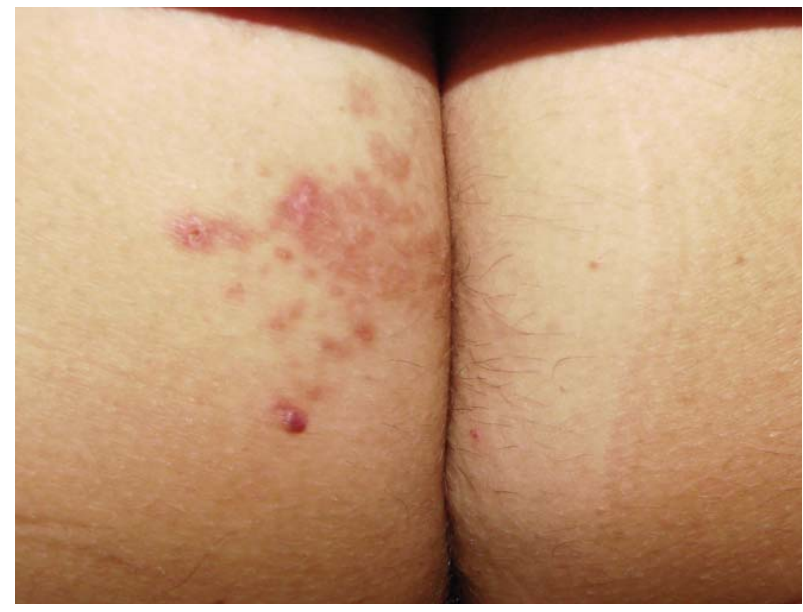

FIGURE 1 : Reddish-coppery cluster of macules and papules at the left buttock

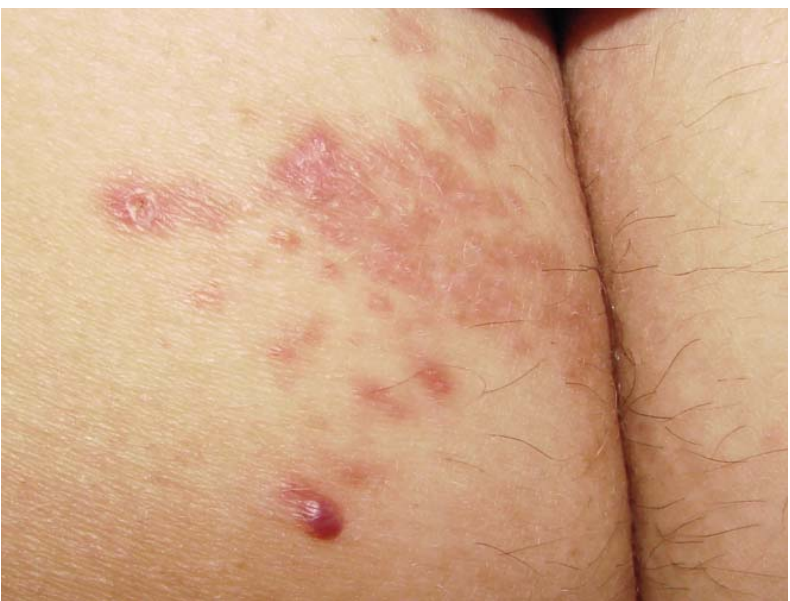

FIGURE 2 : Reddish-coppery macules and papules, clustered and with a smooth surface. One of the lesions is eroded

\section{DISCUSSION}

Ectopic cutaneous schistosomiasis happens when the trematodes' eggs are deposited in the dermis, instead of being eliminated via stools (S. japonicum and S. mansoni) or urine (S. hematobium). ${ }^{1,2}$ The only species reported in Brazil is $S$. mansoni, whose eggs are identified by the presence of a thick lateral spine. ${ }^{3}$ Lesions are typically located at the periumbilical region, torso, superior dorsal region, buttocks, and genital area. They appear as skin-colored papules, sometimes with a reddish-brown coloration, and may spontaneously regress or evolve to lichenified, vegetant or even tumoral lesions. Ulceration and fistulization may also occur. ${ }^{3,45}$

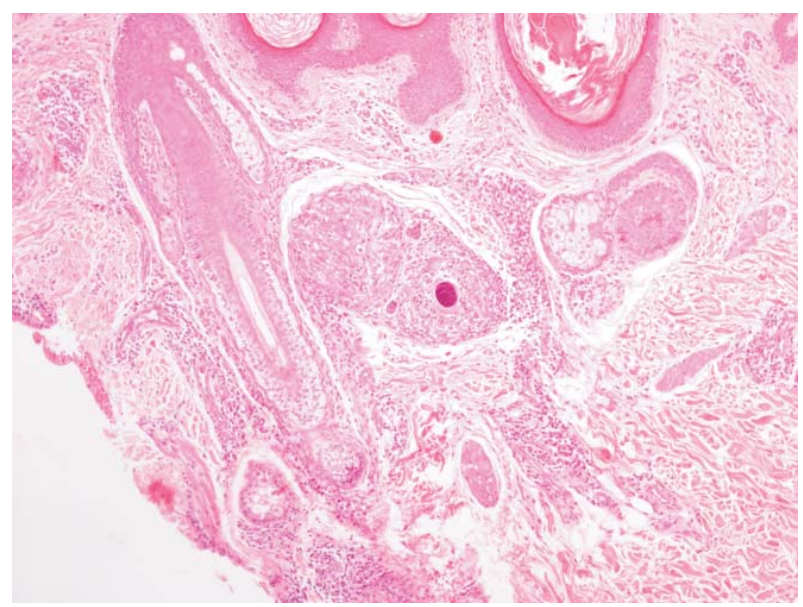

FIGURE 3 : Medium dermis with an epithelioid granuloma surrounding three Schistosoma mansoni eggs. HE, 100X

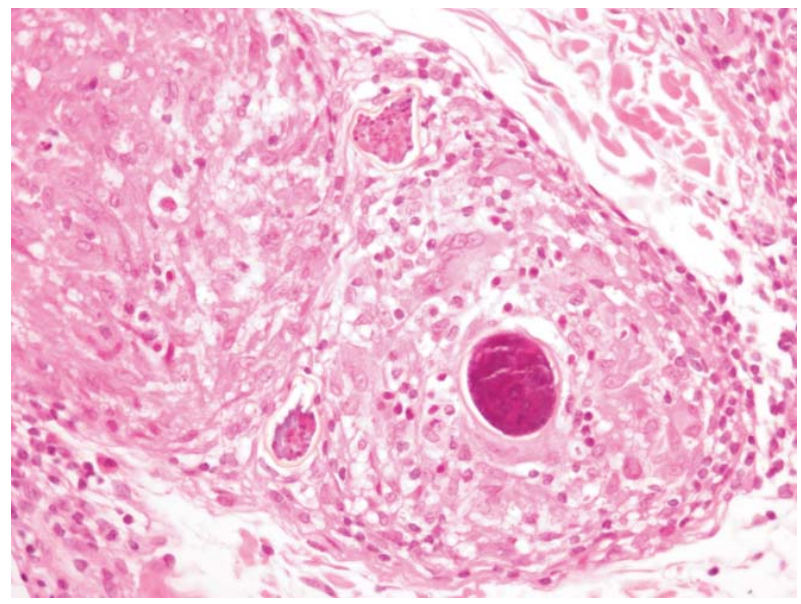

FIGURE 4 : Detail of the three Schistosoma mansoni eggs containing viable miracidia. Notice that the in the eggs on the left side, it is possible to identify the characteristic lateral spine. HE, 400x

There were previous case reports of schistosomiasis in the region of Jacarepaguá. We believe the patient had already contracted the disease previously to this last waterfall bathing, because the acute phase usually presents with hepatoesplenomegalia and the period of egg laying starts 40 days after the infection. ${ }^{3,6,7}$ In the chronic phase of schistosomiasis, the process of egg laying is diminished, and it becomes difficult to detect them on stool samples. Only 2 to $7 \%$ of (chronic) patients develop portal hypertension in Brazil $^{4,6,7} \square$ 


\section{REFERENCES}

1. Andrade Filho Jde S, Lopes MS, Corgozinho Filho AA, Pena GP. Ectopic cutaneous schistosomiasis: report of two cases and a review of the literature. Rev Inst Med Trop São Paulo. 1998;40:253-7.

2. Lopes R, Sousa MAJ, Jeunon T. Tropical troves: what is your diagnosis? Dermatopathol Pract Conc. 2010 [cited 2012 Sep 9];16:3. Available from: http://www.derm101.com.

3. Nunes FC, Costa MCE, Filhote MIF, Sharapinn M. Perfil Epidemiológico da esquistossomose mansônica no bairro Alto da Boa Vista, no Rio de Janeiro. Epidemiological profile o mansonic schistosomiasis at Alto da Boa Vista neighborhood in Rio de Janeiro. Cad Saúde Colet (Rio J). 2005;13:605-16.

4. Carmo EH, Bina JC, Barreto ML. Schistosomiasis related morbidity in Brazil; Spatial distribution, clinical features evolution and medical services assessment. In: Simpósio internacional sobre esquistossomose, Recife-PE. 1997;6:166.

5. Costa IM, Moreira RR, Moraes MA. Esquistossomose mansônica cutânea ectópica. Ectopic cutaneous mansonic schistosomiasis. An Bras Dermatol. 1989;64:183-4.

6. Ferreira LF, Naveira JB, Silva JR. Fase toxêmica da esquistossomose mansoni. Toxemic phase of mansonic schistosomiasis. Rev Inst Med Trop Sao Paulo. 1960;2:112-20.

7. Domingues AL, Medeiros TB, Lopes EP. Ultrasound versus biological markers in the evaluation of periportal fibrosis in human Schistosoma mansoni. Mem Inst Oswaldo Cruz. 2011;106:802-7.

\author{
MAILING ADDRESS: \\ Thiago Jeunon de Sousa Vargas \\ Rua General Roca 778, sala 1005 (grupo) \\ 20521-070 - Rio de Janeiro - RJ \\ Brazil \\ E-mail: thiago.jeunon@gmail.com
}

How to cite this article: Vargas TJS, Lopes R, Moraes MLPFN, Azevedo KGP, Jeunon-Sousa MA. Ectopic cutaneous Schistosomiasis. An Bras Dermatol. 2013;88(5):820-2. 